\title{
Oil Casing Introduction
}

\author{
Hua Tong. Xiao-Hong Tang
}

Mechanical and Electrical Engineering, Southwest Petroleum University, Chengdu, Sichuan, China

\begin{abstract}
Oil casing is the pipe wall, used to support the oil and gas, to ensure normal operation of the post-completion wells at the drilling process. Each well, depending on the depth of drilling and geological conditions, should use several layers of casing. After set down casing will be cementing. Different form tubing and drilling pipe, it cannot be reused, a one-time consumable materials. Therefore, the consumption accounts of casing are over $70 \%$ of all oil well pipes. Casing, according to usage, can be divided into: catheter, surface casing, intermediate casing and production casing. This article provides a briefing including definition on the casing pipe, preparation, use, types, technical specifications, precautions when used.
\end{abstract}

Keywords: oil casing, definition, preparation, structure and specifications

\section{Introduction}

After nearly 20 years of efforts, China's oil casing production starts from scratch, from low-price to high-price, low-grade steel products to the API casing and then to the special non-API products, from quantity to quality are close the level of foreign oil casing production. Domestic market share of OCTG has exceeded $80 \%$, and has been for many years to become a net exporter of the product.

According to the "2013--2017 China's oil casing industry sales forecast demand and investment analysis report" statistics, in 2011, China's crude oil output reached 204 million tons, compared with the same period in 2010 grew $0.32 \%$; natural gas production reached 102.531 billion cubic meters, an increase to $6.9 \%$, a high record. China is still in urbanization, industrialization and rapid development stage, the next few years, oil demand average annual growth about $4 \%$. The growing demand for oil contributed to the rise of oil drilling equipment demand.

From our domestic regional distribution, oil casing needs no longer concentrated in the eastern region. From the domestic oil and gas field development trend, from the initial development of Daqing, Liaohe, Shengli Oilfield in eastern oilfields, later turned west Sichuan, Xinjiang and other development. Trend to concern offshore oil fields, will also be to the beach, from the shallow to the deep sea land. CNAC think steel drilling depth are deeper, drilling work situation become increasingly complex, the requirements for oil casing inevitably increase.

\section{Definition of Oil Casing}

OCTG mainly used for oil and gas well drilling and oil and gas transportation. It includes oil drilling pipe, oil casing, pump tubing. Oil drill pipes are mainly used to connect drill collar and drill and pass drilling power. Oil casing is mainly used to support the borehole after drilling and completion, to ensure that the conduct and completion of the drilling process after the normal operation of the entire oil wells. Pump tubing main function are pumping oil and gas from bottom to floor.

Oil casing is the lifeline maintaining well running. Due to different geological conditions, stress state is complex underground. Tensile, compressive, bending, tensional stress jointly affect on the tube, which makes the casing itself, need the higher quality requirements. Once the casing itself damaged for some reason, it could lead to the whole wells' production reduced, or even scrapped.

According to the strength of the steel casing, they can be divided into different steel grades, namely J55, K55, N80, L80, C90, T95, P110, Q125, V150 and other. Under well conditions, different depth, the steel grade of casing is also different. In corrosive environments casing itself also requires corrosion resistance. In place of complex geological conditions casing also require anti-collapse properties.

\section{Preparation}

$27 \mathrm{MnCrV}$ is the new steel to product TP110T grade oil tubing. Conventional oil production TP110T grade steel casing are $29 \mathrm{CrMo} 44$ and $26 \mathrm{CrMo} 4$. Compared to the post both, $27 \mathrm{MnCrV}$ contained less Mo element, can greatly reduce the production cost. However, after the use of normal austenitic hardened process for producing, $27 \mathrm{MnCrV}$ exist significant temperature temper brittleness, resulting in low toughness and unstable.

Solving those problems usually has two ways. One way is that applying tempering and rapid cooling is to avoid temperature brittleness, and obtain toughness. The second way is subcritical quenching that through steel incomplete austenite, effectively improve the harmful elements and impurities, and improve toughness. For the first method, heat treatment equipment requirements is relatively strict, we need to add extra cost.

$27 \mathrm{MnCrV}$ steel, $\mathrm{AC} 1=736^{\circ} \mathrm{C}, \mathrm{AC} 3=810^{\circ} \mathrm{C}$, heating temperature select between $740-810{ }^{\circ} \mathrm{C}$ when subcritical quenching. Subcritical quenching select the heating temperature $780{ }^{\circ} \mathrm{C}$, quenching time holding $15 \mathrm{~min}$; quenching and tempering selected temperature as $630^{\circ} \mathrm{C}$, tempering heating time holding $50 \mathrm{~min}$. Since subcritical quenching is in the $\alpha+\gamma$ two-phase region, quenched while retaining part of undisclosed ferrite state, which not only maintain high strength but also toughness is improved.

Meanwhile temperature of low-temperature quenching is lower than conventional temperature, reducing quenching 


\section{International Journal of Science and Research (IJSR) \\ ISSN (Online): 2319-7064}

Index Copernicus Value (2013): 6.14 | Impact Factor (2015): 6.391

stress. Thus reduce the quenching distortion, and ensure the smooth operation of the production of heat treatment. But also for the subsequent Silk processing provide a good raw material.

The process has been applied in Tianjin Pipe Group's pipe factory. Warranty data shows that the yield strength of steel after heat treatment, its Rt0.6 is in $820-860 \mathrm{MPa}$, tensile strength is in $910-940 \mathrm{MPa}$, impact toughness is in $65-85 \mathrm{~J}$, invulnerability performance is $100 \%$ qualified. Data show that, $27 \mathrm{MnCrV}$ pipe is already quite high quality steel grade oil casing, on the other hand also shows that subcritical quenching process is an excellent method for the production of steel products to avoid brittleness when hot.

\section{Usage and Status}

Oil Casing is a large-diameter pipe, played the role of fixed oil and gas wells, or wellbore wall. Casing is inserted into the wellbore, fixed with cement to prevent the borehole formation and borehole collapse, which to ensure the drilling mud circulation, to facilitate drilling mining.

Oil casing steel grade: H40, J55, K55, N80, L80, C90, T95, P110, Q125, V150 and other. End of the tube processing forms: short round thread, long round thread, buttress thread, special joint. Mainly use to support the borehole after drilling and completion to ensure the completion of the drilling process after the normal operation of the entire oil wells.

Oil industry is the industrial extensive using oil pipe, and oil pipe accounts for a very important position in the petroleum industry:

1) The amount of oil casing is large, and with high cost, having great savings, cost reduction potential. The annual consumption of OCTG can be calculated by drilling capacity. According to China's specific conditions, each drilling $1 \mathrm{~m}$ generally requires OCTG $62 \mathrm{~kg}$, wherein the casing $48 \mathrm{~kg}$, tubing $10 \mathrm{~kg}$, Drill $3 \mathrm{~kg}$, drill collar $0.5 \mathrm{~kg}$.

2) Mechanical and Environmental Behavior of oil pipe on the oil industry with advanced technology and production efficiency have a significant impact.

3) Oil pipe failure with huge losses, its safety, reliability and longevity are at great stake for oil industry.

\section{Species}

Different types of casing are used in oil extraction process. Surface oil casing, protect drilling to avoid the contamination of shallow aquifers and shallow gas, supporting wellhead equipment and other layers to keep the weight of the casing. Technical Oil casing, separate the different levels pressure, make the drilling flow fluid normal and protect the production casing. It is easy to install anti-burst, leak-proof device, and the tailpipe in the drilling. Oil casing, export the oil and gas from the reservoir layer under the surface to protect drilling and lay the drilling mud. Typically, its outside diameter is in $114.3-508 \mathrm{~mm}$.

Oil Casing type selection and installation should accord to SY / T6194-96. "Oil casing" has short thread casing and couplings, long thread casing and coupling two kinds.

\section{6 Technical Specifications}

1) According to domestic casing SY / T6194-96 regulations, casing length is not fixed, ranged in $8-13 \mathrm{~m}$. But not less than $6 \mathrm{~m}$ casing may be provided, which shall not exceed $20 \%$.

2) Casing internal and external surface shall not fold, hairline, separation, crack, rolling fold and scarring. These defects should be completely removed, and clearing the depth may not exceed $12.5 \%$ of the nominal wall thickness.

3) Coupling outer surface may not have fold, hair pattern, separation, crack, rolled off, scarring and other defects.

4) Casing and threaded coupling surface should be smooth, it does not allow burr, tear and impact strength sufficient to interrupt threads and other defects tight junctions.

\section{Caution when used}

1) First, do a good job of water quality standards, strict testing and quality management. Implementation of separate sewage water injection to enhance cleaning of the main water pipes, so the station, the bottom water quality standards, reduce corrosion source into the annular space

2) For new production of injection wells, taken mainly sterilization annulus protection fluid and forms a system of regular.

3) Due to acceleration for mechanical abrasion on the casing pipe, recommended that tubing coupling plus a rubber ring or, at inclination serious parts, plus a centralizer, avoiding when tubing during operation and during the injection, scratched the side of the casing.

4) Injected regularly to the annulus 100 degrees Celsius temperature water or steam to kill the SRB under the dirt.

5) Before in injection wells casing corrosion has not been effectively controlled, it is not recommended to use catholic protection and casing coating.

\section{Conclusion}

1) It proposed to reduce or cease production of drilling pipe or production line, mainly product N80 or J55 for surface casing.

2) On this basis, focusing on the development of these high-quality, high-performance OCTG. High antibody casing should also have anti-extrusion resistance, high temperature resistance, corrosion resistance, tensile good overall performance. Although the domestic production of some intermediate casing has a small bulk supply of deep well, but imports still dominant. As for deep Casing, its size, depth and technical parameters when used should be controlled within the range of accuracy. Casing pipes centering has a small amount, currently mainly imported, but our Western South Triangle offshore construction company produce about 400 roots annually. With the development of natural gas, special threaded joints with the original oval, partial ladder threaded couplings, no

\section{Volume 5 Issue 6, June 2016}




\section{International Journal of Science and Research (IJSR) \\ ISSN (Online): 2319-7064}

Index Copernicus Value (2013): 6.14 | Impact Factor (2015): 6.391

longer meet the requirements and urgent need to supply special casing threaded joint, which is a potentially huge market has appeared.

3) Consider using straight seam resistance welding casing (API5CT) to substitute seamless steel pipe, one side can reduce the cost, on the other hand can reduce the dependence on the tube.

\section{References}

[1] Yu H, Zhang LH, Lin TJ. Finite Element Analysis of Failure Mechanism of Casing during Shale Gas Fracturing [J].China Petroleum Machinery, 2014, 42(8):84-88(in Chinese).

[2] Sugden C, Johnson J, Chambers M. Special Considerations in the Design Optimization of the Production Casing in High- rate, Multistage- Fractured Shale Wells [J]. SPE151470,2012.

[3] Gao LX, Jin Y. Seal design of premium threaded casing connection [J].Chinese Journal of Mechanical Engineering, 2005, 41 (3) :216-219(in Chinese).

[4] Yang X W, Ju Y F. Studied about cement sheath defects affecting on casing connection strength [J]. Oil Field Equipment, 2007, 36(9):49-52.

[5] Wang L, Zhang RX, Liu YW, Zou JX, Zang Y, Zou WZ, $\mathrm{Lu} X Q$. Gluing failure analysis of API round thread casing connection [J].Iron and Steel, 2000, 5 (35):44-47(in Chinese).

[6] Pang B Q, Yang S, Dou Y H. Casing Wear and cement sheath defect position on Casing Stress [J]. Petroleum machinery, 2009, 37(10):1-3.

[7] De Andrade J, Torsaeter M and Opedal N. Influence of Casing Centralization on Cement Sheath Integrity During Thermal Cycling[J] IADC/SPE 168012,2014.

[8] Zhu HJ, Lin YH, Zeng DZ, Zhang DP, Wang F,2012. Calculation analysis of sustained casing pressure in gas wells. Petroleum Science, (1):66 74(in Chinese).

[9] Yang M H, Xia H N. Casing string design and strength check of HPHT well [J].Oil Drilling Technology, 2002 (30): 26-27. (in Chinese)

[10] Kang X L. Sealing structure of the oil casing connected threads [J]. Field Equipment, 1997, 20 (1): 47-50.

Volume 5 Issue 6, June 2016 www.ijsr.net 